Gastric cancer is a common and deadly cancer. Several factors are associated with its prognosis; however, controversy exists about the role of microsatellite instability (MSI). We aimed to determine the 5 -year overall survival (OS) of MSI in gastric adenocarcinoma.

A cross-sectional study was carried out on gastric adenocarcinoma in clinical stages I to III treated with D2 gastrectomy between 2010-2013. MSI was demonstrated by immunohistochemistry. We performed a survival analysis comparing cases with and without MSI.

From 102 cases, $9.8 \%$ showed MSI. The median age was 63 years (range 33-91 years), and $57.8 \%$ were men. The more prevalent site of occurrence was the antrum (46.1\%), $78.5 \%$ of the cases presented in stage III, $47.1 \%$ were of the diffuse type, $45.1 \%$ were of an intestinal type, and $7.8 \%$ were mixed. MSI cases were associated with lower clinical stages (stages I-II) and with better 5 -year OS (100 vs. 47 months, $p=0.017$ ). In a multivariate analysis, MSI was independently associated with better survival $(\mathrm{HR}=$ $0.209,95 \%$ Cl: $0.046-0.945, p=0.042$ ) MSI gastric cancers presented in early clinical stages and had favourable prognosis compared with non-MSI cancers.

Key words: gastric cancer, microsatellite instability, immunohistochemistry, cancer prognosis, overall survival.

Contemp Oncol (Pozn) 2021; 25 (1): 68-71 DOI:https://doi.org/10.5114/wo.2021.104939

\section{Prognostic impact of microsatellite instability in gastric cancer}

\author{
Cesar Zepeda-Najar ${ }^{1}$, Rodrigo Xavier Palacios-Astudillo², \\ Jazmín Danaé Chávez-Hernández ${ }^{2}$, Leonardo Saul Lino-Silva², \\ Rosa A. Salcedo-Hernández ${ }^{2}$
}

${ }^{1}$ Surgical Oncology Division, Hospital Ángeles Tijuana, Mexico

${ }^{2}$ Surgical Pathology, Instituto Nacional de Cancerología de México, Mexico

\section{Introduction}

Gastric adenocarcinoma is the second malignancy of the gastrointestinal tract and corresponds to 95\% of all primary malignant tumours originated in this organ, and it has a poor prognosis; based on GLOBOCAN 2018 data, stomach cancer is the 5th most common neoplasm and the 3rd most deadly cancer, with an estimated 783,000 deaths in 2018 [1]. In recent years, the study of the molecular basis of neoplasms has begun, including gastric adenocarcinoma [2].

Microsatellite instability (MSI) occurs by defective repair of mismatching base pairs of methylated DNA (MMR), and it manifests as an abnormal length (increased or decreased) of the microsatellite repeats. The presence of MSI is a sign of deficiency in the repair of the mismatch of the DNA that in several cancers has shown prognostic impact $[3,4]$.

In gastric cancer, 2 systematic reviews demonstrated the better prognosis of MSI, but both showed high heterogeneity, the methodology for MSI detection was not standardized and was based on molecular analysis, the selection of patients varied across studies, and no neoadjuvant studies were included $[4,5]$. MSI is detected only in cases of intestinal type, where it is statistically related to the progression of the disease [6]. MSI is present in $10-30 \%$ of cases [7].

The inactivation of the genes that repair replication errors leads (in most cases) to a loss of immunohistochemical (IHC) expression of the proteins encoded by these genes. In most of the studies and based on systematic reviews, the sensitivity and specificity of $\mathrm{IHC}$ for the identification of MSI are very high (>90\%), and the IHC expression analysis is a simple and inexpensive technique that is easy to perform in any laboratory where $\mathrm{IHC}$ staining is done routinely [8].

Our objective was to determine the 5-year overall survival (5-yr OS) of the MSI status demonstrated by IHC in gastric adenocarcinoma (both intestinal and diffuse cases), including cases with neoadjuvant therapy.

\section{Material and methods}

A cross-sectional study was carried out. All patients (> 18-years old) presented consecutively consulting for gastric adenocarcinoma between 2010 and 2013 were identified. We selected the cases in clinical stages I-III treated with D2 gastrectomy (median lymph node retrieval 46 nodes, range 29-115). We excluded stage IV patients due to its intrinsically poor prognosis, cases with carcinoma of the oesophagus or the oesophagogastric junction, cases that did not meet the pre-analytic requirements recommended for IHC studies (good fixation, use of buffered formalin, good preservation of paraffin blocks), and cases with absence of material for IHC.

The following data were collected from the files: age, sex, location of the lesion, presence of gastritis, infection by Helicobacter pylori, the presence of gastric atrophy, tumourtype, HER2 status, histological grade, clinical stage, and 
overall survival. All the surgical samples were re-reviewed by 2 pathologists, and the IHC determination of the MMR proteins (anti-MLH1 [clone M1-Ventana, Oro Valley, AZ, US], anti-MSH2 [clone G219-1129 - Cellmarque, Rocklin, CA, US], anti-MSH6 [clone 44-Ventana], anti-PMS2 [clone EPR 3947 - Cellmarque]) was carried out as recommended in the consensus for the determination of MMR by IHC in colorectal cancer: the presence of nuclear expression in any percentage of the 4 proteins classified the case as microsatellite stable. Otherwise, the absence of at least one of the MMR proteins classify the case as MSI.

The primary outcome of this study was to determine if the presence of MSI in the gastric adenocarcinoma affects the 5-year OS of patients in I-III clinical stages. For all numerical variables we applied the Kolmogorov-Smirnov test to determine their normality. Data are represented as count and percentage for categorical variables and mean with standard deviation (SD) for numerical variables with parametric distribution, and we used medians and interquartile range (IQR) for non-paramet-

Table 1. Clinicopathologic features of 102 cases of gastric adenocarcinoma according their microsatellite instability status

\begin{tabular}{|c|c|c|c|}
\hline Variable & $\begin{array}{c}\text { Non MSI cases } \\
\quad(n=92)\end{array}$ & $\begin{array}{c}\text { MSI cases } \\
(n=10)\end{array}$ & $p$-value \\
\hline $\begin{array}{l}\text { Sex }-n(\%) \\
\text { Female } \\
\text { Male }\end{array}$ & $\begin{array}{l}39(42.4) \\
53(57.6)\end{array}$ & $\begin{array}{l}4(40) \\
6(60)\end{array}$ & 1.00 \\
\hline $\begin{array}{l}\text { Tumour site }-n(\%) \\
\text { Fundus } \\
\text { Corpus } \\
\text { Antrum }\end{array}$ & $\begin{array}{l}10(10.9) \\
40(43.5) \\
42(45.7)\end{array}$ & $\begin{array}{l}1(10) \\
4(40) \\
5(50)\end{array}$ & 0.570 \\
\hline $\begin{array}{l}\text { Clinical stage }-n(\%) \\
\text { II } \\
\text { III }\end{array}$ & $\begin{array}{c}4(4.3) \\
12(13) \\
76(82.7)\end{array}$ & $\begin{array}{l}1(10) \\
5(50) \\
4(40)\end{array}$ & 0.009 \\
\hline $\begin{array}{l}\text { Histologic subtype }-n(\%) \\
\text { Intestinal } \\
\text { Diffuse } \\
\text { Mixed }\end{array}$ & $\begin{array}{c}39(42.4) \\
45(48.9) \\
8(8.7)\end{array}$ & $\begin{array}{l}7(70) \\
3(30) \\
-\end{array}$ & 0.322 \\
\hline $\begin{array}{l}\text { Histologic grade }-n(\%) \\
\text { G1 } \\
\text { G2 } \\
\text { G3 }\end{array}$ & $\begin{array}{c}4(4.3) \\
17(18.5) \\
71(77.2)\end{array}$ & $\begin{array}{l}1(10) \\
4(40) \\
5(50)\end{array}$ & 0.129 \\
\hline $\begin{array}{l}\text { Chronic gastritis }-n(\%) \\
\text { No } \\
\text { Yes }\end{array}$ & $\begin{array}{c}8(8.7) \\
84(91.3)\end{array}$ & $\begin{array}{l}1(10) \\
9(90)\end{array}$ & 1.00 \\
\hline $\begin{array}{l}\text { Helicobacter pylori }-n(\%) \\
\text { No } \\
\text { Yes }\end{array}$ & $\begin{array}{l}58(63) \\
34(37)\end{array}$ & $\begin{array}{l}7(70) \\
3(30)\end{array}$ & 0.744 \\
\hline $\begin{array}{l}\text { Atrophy }-n(\%) \\
\text { No } \\
\text { Yes }\end{array}$ & $\begin{array}{l}82(89.1) \\
10(10.9)\end{array}$ & $\begin{array}{l}8(80) \\
2(20)\end{array}$ & 0.334 \\
\hline $\begin{array}{l}\text { Metaplasia }-n(\%) \\
\text { No } \\
\text { Yes }\end{array}$ & $\begin{array}{l}59(64.1) \\
33(35.9)\end{array}$ & $\begin{array}{l}6(60) \\
4(40)\end{array}$ & 0.603 \\
\hline $\begin{array}{l}\text { Her2 status - n (\%) } \\
\text { Negative } \\
\text { Indeterminate } \\
\text { Positive }\end{array}$ & $\begin{array}{c}88(95.7) \\
1(1.1) \\
3(3.3)\end{array}$ & $\begin{array}{c}9(90) \\
0 \\
1(10)\end{array}$ & 0.410 \\
\hline
\end{tabular}

ric data. We used ANOVA or U Mann-Whitney testing for numerical variables and $\chi^{2}$ tests for categorical variables. We performed a univariate analysis with Kaplan-Meier curves to describe OS, and log-rank tests to compare the cumulative survival distributions between the groups. The Cox proportional hazard model for multivariate analysis was performed, adjusting the model for age, sex, and all variables with $p<0.10$ in the univariate analysis. For all calculations, we set the statistical significance as a $p$-value < 0.05. We used SPSS 22.0 (SPSS, Chicago, IL, USA) to perform all statistics.

\section{Results}

Table 1 summarizes the variables according to the MSI status. From the 102 cases, 10 showed MSI (9.8\%). The median age was 63 years (range 33-91 years), and 57.8\% (59 cases) were men. The more prevalent site of occurrence was the antrum (46.1\%) followed by the corpus (43.1\%) and fundus (10.8\%). From all cases, $78.4 \%$ presented in stage III. Regarding pathologic features, $47.1 \%$ were of diffuse type, $45.1 \%$ were of an intestinal type, and $7.8 \%$ were mixed type; whereas $74.5 \%$ were poorly differentiated (G3), 91.2\% had chronic gastritis (36.3\% caused by H. pylori and $11.8 \%$ had atrophy), and $36.3 \%$ showed intestinal metaplasia. Her 2 status was positive (score $3+$ ) in 4 cases (3.9\%) and negative in the remaining cases. From Table 1 is clear that MSI cases presented in earlier clinical stages (stages I-II) compared to MSS cases.

Regarding outcomes, 14 (13.7\%) cases recurred, 13 in the microsatellite stable group ( $p=0.708)$, and $72(70.6 \%)$ cases died, with a significant 5-yr OS between groups (Table 1, Fig. 1). In a stratified analysis by clinical stage, the difference in survival remained for patients with MSI.

Table 2 shows the factors associated with survival in the 102 cases. The factors associated with poor survival were male sex, MSS cases, and being Her 2 negative. In a multivariate analysis,

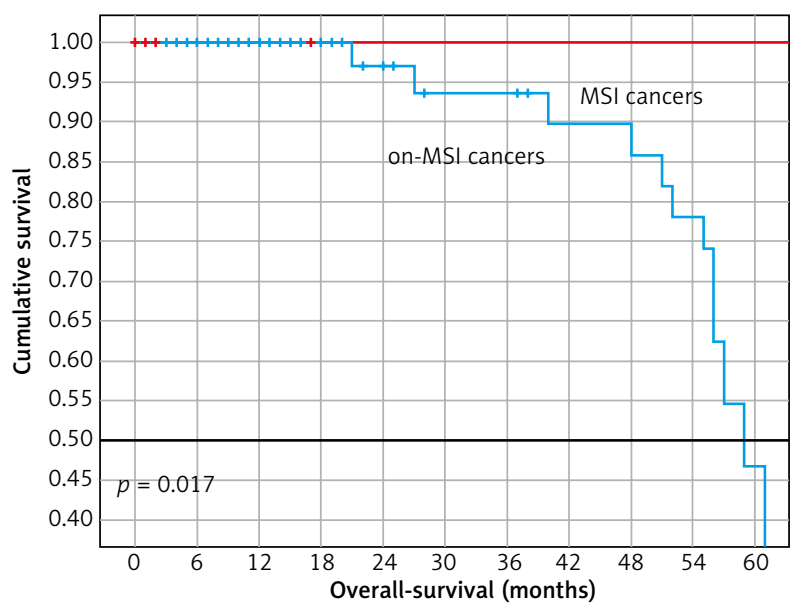

Fig. 1. Kaplan-Meier survival curves of patients with gastric adenocarcinomas with determination of microsatellite instability by immunohistochemistry. Patients with microsatellite instability showed favourable overall survival 
Table 2. Factors associated with survival of 102 cases with gastric cancer treated by surgery from 2010 to 2013

\begin{tabular}{|c|c|c|}
\hline Factor & $\begin{array}{l}\text { Median of survival } \\
\text { (months) }\end{array}$ & $p$-value \\
\hline $\begin{array}{l}\text { Sex } \\
\text { Male } \\
\text { Female }\end{array}$ & $\begin{array}{l}59 \\
68\end{array}$ & 0.012 \\
\hline $\begin{array}{l}\text { Initial treatment } \\
\text { Surgery } \\
\text { Chemo-radiotherapy }\end{array}$ & $\begin{array}{l}61 \\
61\end{array}$ & 0.759 \\
\hline $\begin{array}{l}\text { Location } \\
\text { Fundus } \\
\text { Corpus } \\
\text { Antrum }\end{array}$ & $\begin{array}{l}72 \\
61 \\
57\end{array}$ & 0.637 \\
\hline $\begin{array}{l}\text { Clinical stage } \\
\text { I } \\
\text { III }\end{array}$ & $\begin{array}{l}79 \\
57 \\
57\end{array}$ & 0.209 \\
\hline $\begin{array}{l}\text { Subtype } \\
\text { Intestinal } \\
\text { Diffuse } \\
\text { Mixed }\end{array}$ & $\begin{array}{l}61 \\
64 \\
59\end{array}$ & 0.777 \\
\hline $\begin{array}{l}\text { Histologic grade } \\
\text { G1/G2 } \\
\text { G3 }\end{array}$ & $\begin{array}{l}57 \\
61\end{array}$ & 0.751 \\
\hline $\begin{array}{l}\text { Gastritis } \\
\text { No } \\
\text { Yes }\end{array}$ & $\begin{array}{l}59 \\
61\end{array}$ & 0.764 \\
\hline $\begin{array}{l}\text { Helicobacter pylori } \\
\text { No } \\
\text { Yes }\end{array}$ & $\begin{array}{l}61 \\
61\end{array}$ & 0.604 \\
\hline $\begin{array}{l}\text { Atrophy } \\
\text { No } \\
\text { Yes }\end{array}$ & $\begin{array}{l}61 \\
40\end{array}$ & 0.518 \\
\hline $\begin{array}{l}\text { Her2 } \\
\text { Negative } \\
\text { Positive }\end{array}$ & $\begin{array}{l}59 \\
95\end{array}$ & 0.035 \\
\hline $\begin{array}{l}\text { Metaplasia } \\
\text { No } \\
\text { Yes }\end{array}$ & $\begin{array}{l}35.4 \\
36.9\end{array}$ & 0.911 \\
\hline $\begin{array}{l}\text { Microsatellite instability } \\
\text { No } \\
\text { Yes }\end{array}$ & $\begin{array}{c}100 \\
47\end{array}$ & 0.017 \\
\hline
\end{tabular}

the MSI was independently associated with better survival (HR 0.209, 95\% Cl: 0.046-0.945, $p=0.042$, Table 3).

\section{Discussion}

In summary, of the 102 patients reviewed, 92 patients were MSS, and only 10 patients (9.8\%) were MSI. MSI was associated with lower clinical stages, less recurrence, and better 5-year survival.

MMR deficiency noted in sporadic gastric cancers is caused by promoter methylation and the consequent suppression of transcription of MLH1. The MMR deficiency results in the accumulation of frameshift mutations of many target genes that have repetitive sequences in their coding region [9]. As a result, MSI gastric cancers follow a unique, multistep carcinogenesis pathway. It has been published
Table 3. Multivariate analysis of factors associated with survival of 102 cases of gastric carcinoma

$\begin{array}{lccc}\text { Variable } & \begin{array}{c}\text { Hazard } \\ \text { ratio }\end{array} & \begin{array}{c}95 \% \text { confident } \\ \text { interval }\end{array} & p \text {-value } \\ \begin{array}{l}\text { MSI status } \\ \text { (MSI vs. non-MSI) }\end{array} & 0.209 & 0.046-0.945 & 0.042 \\ \begin{array}{l}\text { Mitosis } \\ (>1 \text { vs. }<1)\end{array} & 2.491 & 1.644-3.755 & <0.001 \\ \begin{array}{l}\text { Sex } \\ \text { (Male vs. female) }\end{array} & 0.467 & 0.172-1.268 & 0.135 \\ \begin{array}{l}\text { Her2 status } \\ \text { (Positive vs. negative) }\end{array} & 0.095 & 0.009-1.056 & 0.055\end{array}$

that MSI gastric cancers are thought to have different clinicopathological features compared to other groups that support the "classic" or "chromosomal instability" pathway, an association with female sex, older age, intestinal type, mid/lower gastric location, lack of lymph node metastasis, and TNM stages I-II [4]. We did not find any clinicopathologic differences between groups except clinical stages I-II, according to data from other published studies (Fang). A plausible explanation is that several of the published series focused on intestinal-type adenocarcinomas, whereas we included all gastric carcinoma subtypes.

There is a prognosis discrepancy of MSI in gastric carcinoma. A better prognosis of MSI has been reported in some studies [10-15], especially in intestinal adenocarcinomas and those with distal location $[16,17]$, but not in others $[18,19]$. This discrepancy could be explained by different incidence (8.2-37\%), use of different MSI definitions, determination of MSI status by tissue microarrays, or the limited numbers of cases (11-83 cases) of the previous studies. We found that the MSI cases had a better prognosis $(p=0.042)$.

Finally, in this study, we found that the frequency of MSI-H gastric cancers was $9.8 \%$. This frequency is in agreement with the data of previous studies - from $8.2 \%$ to $9.6 \%$ $[18,20,21]$.

Some limitations exist in the present study: this was a single-centre study, and some of the groups had a small number of cases (particularly the Her 2-positive cases). Among the strengths, our research is based on a public high-volume cancer centre; the sample represents Latin patients treated with potentially curative intent by high-volume surgeons were standard D2-gastrectomy was performed, the pathologic evaluation is well standardized, and the period of patients' recruitment is short, which makes possible a standardized and homogeneous criteria for treatment.

\section{Conclusions}

We demonstrated that MSI gastric cancers presented in early clinical stages and harbors an independent, favorable prognostic factor. This finding indicates that MSI gastric cancers are a different subset of gastric cancers that predict favourable prognosis. 
The authors declare no conflict of interest.

\section{References}

1. Rawla P, Barsouk A. Epidemiology of gastric cancer: global trends, risk factors and prevention. Prz Gastroenterol 2019; 14: 26-38.

2. Nakajima M, Sawada H, Yamada $Y$, et al. The prognostic significance of amplification and overexpression of c-met and c-erb B-2 in human gastric carcinomas. Cancer 1999; 85: 1894-1902.

3. Richard SM, Bailliet G, Páez GL, Bianchi MS, Peltomäki P, Bianchi NO. Nuclear and mitochondrial genome instability in human breast cancer. Cancer Res 2000; 60: 4231-4237

4. Polom K, Marano L, Marrelli D, et al. Meta-analysis of microsatel lite instability in relation to clinicopathological characteristics and overall survival in gastric cancer. Br J Surg 2018; 105: 159-167.

5. Choi YY, Bae JM, An JY, et al. Is microsatellite instability a prognostic marker in gastric cancer?: a systematic review with meta-analysis. J Surg Oncol 2014; 110: 129-135.

6. Jeong CW, Lee JH, Sohn SS, Ryu SW, Kim DK. Mitochondrial micro satellite instability in gastric cancer and gastric epithelial dysplasia as a precancerous lesion. Cancer Epidemiol 2010; 34: 323-327.

7. Buonsanti G, Calistri D, Padovan L, et al. Microsatellite instability in intestinal and diffuse-type gastric carcinoma. J Pathol 1997; 182: 167-173.

8. Snowsill T, Coelho H, Huxley N, Jones-Hughes T, Briscoe S, Frayling IM, Hyde C. Molecular testing for Lynch syndrome in people with colorectal cancer: systematic reviews and economic evaluation. Health Technol Assess 2017; 21: 1-238.

9. Kim JJ, Baek MJ, Kim L, et al. Accumulated frameshift mutations at coding nucleotide repeats during the progression of gastric carcinoma with microsatellite instability. Lab Invest 1999; 79: 1113 1120 .

10. Yamamoto H, Perez-Piteira J, Yoshida T, et al. Gastric cancers of the microsatellite mutator phenotype display characteristic genetic and clinical features. Gastroenterol 1999; 116: 1348-1357.

11. Falchetti M, Saieva C, Lupi R, et al. Gastric cancer with high-level microsatellite instability: target gene mutations, clinicopathologic features, and long-term survival. Hum Pathol 2008; 39: 925-932.

12. dos Santos NR, Seruca R, Constancia M, Seixas M, SobrinhoSimoes M. Microsatellite instability at multiple loci in gastric carcinoma: clinicopathologic implications and prognosis. Gastroenterol 1996; 110: 38-44.

13. Kim H, An JY, Noh SH, Shin SK, Lee YC, Kim H. High microsatellite instability predicts good prognosis in intestinal-type gastric cancers. J Gastroenterol Hepatol 2011; 26: 585-592.

14. Fang WL, Chang SC, Lan YT, et al. Microsatellite instability is associated with a better prognosis for gastric cancer patients after curative surgery. World J Surg 2012; 36: 2131-2138.

15. Roh CY, Choi YY, Choi S, et al. Single patient classifier assay, mi crosatellite instability, and epstein-barr virus status predict clinical outcomes in stage II/III gastric cancer: results from CLASSIC trial. Yonsei Med J 2019; 60: 132-139.

16. Marrelli D, Polom K, Pascale V, et al. Strong prognostic value of microsatellite instability in intestinal type non-cardia gastric cancer. Ann Surg Oncol 2016; 23: 943-950.

17. Pereira MA, Ramos MFKP, Faraj SF, et al. Clinicopathological and prognostic features of Epstein-Barr virus infection, microsatellite instability, and PD-L1 expression in gastric cancer. J Surg Oncol 2018; 117: 829-839.

18. Seo HM, Chang YS, Joo SH, et al. Clinicopathologic characteristics and outcomes of gastric cancers with the MSI-H phenotype. J Surg Oncol 2009; 99: 143-147.

19. Wirtz HC, Muller W, Noguchi T, et al. Prognostic value and clinicopathological profile of microsatellite instability in gastric cancer. Clin Cancer Res 1998; 4: 1749-1754.

20. Gu M, Kim D, Bae Y, Choi J, Kim S, Song S. Analysis of microsatellite instability, protein expression and methylation status of hMLH1 and hMSH2 genes in gastric carcinomas. Hepatogastroenterology 2009; 56: 899-904.
21. Oki E, Kakeji Y, Zhao Y, et al. Chemosensitivity and survival in gastric cancer patients with microsatellite instability. Ann Surg Oncol 2009; 16: 2510-2515

\section{Address for correspondence}

\section{MSc Leonardo Saul Lino-Silva}

Instituto Nacional De Cancerologia de Mèxico

Av. San Fernando 22

Sección XVI, Tlalpan

Mexico City

Mexico, 14080

e-mail: saul.lino.sil@gmail.com

Submitted: 2.10 .2020

Accepted: 6.11 .2020 